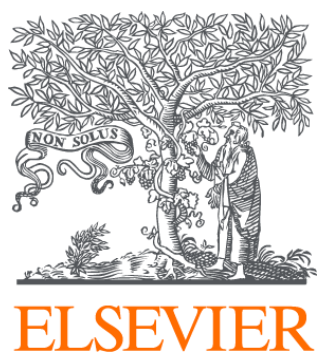

Since January 2020 Elsevier has created a COVID-19 resource centre with free information in English and Mandarin on the novel coronavirus COVID-

19. The COVID-19 resource centre is hosted on Elsevier Connect, the company's public news and information website.

Elsevier hereby grants permission to make all its COVID-19-related research that is available on the COVID-19 resource centre - including this research content - immediately available in PubMed Central and other publicly funded repositories, such as the WHO COVID database with rights for unrestricted research re-use and analyses in any form or by any means with acknowledgement of the original source. These permissions are granted for free by Elsevier for as long as the COVID-19 resource centre remains active. 


\title{
Impact of Covid-19 lockdown on $\mathrm{PM}_{10}, \mathrm{SO}_{2}$ and $\mathrm{NO}_{2}$ concentrations in Salé City (Morocco)
}

\author{
Anas Otmani ${ }^{\mathrm{a}, \mathrm{c}}$, Abdelfettah Benchrif $^{\mathrm{b}, *}$, Mounia Tahri $^{\mathrm{b}}$, Moussa Bounakhla ${ }^{\mathrm{b}}$, El Mahjoub Chakir ${ }^{\mathrm{a}}$, \\ Mohammed El Bouch ${ }^{\mathrm{c}}$, M'hamed Krombi $^{\mathrm{d}}$
}

a Faculty of Sciences, Ibn Tofail University, Kenitra, Morocco

${ }^{b}$ National Centre for Nuclear Energy, Science and Technology (CNESTEN), Morocco

${ }^{c}$ Laboratoire National des Études et de Surveillance de la Pollution (LNESP), Morocco

d Direction Régionale de la Culture, Ministère de la Culture, Morocco

\section{H I G H L I G H T S}

- $\mathrm{PM}_{10}, \mathrm{NO}_{2}$ and $\mathrm{SO}_{2}$ concentrations were reduced by more than half during the covid-19 lockdown period.

- Covid-19 countermeasures contribute to reduce all pollutant concentrations but with significant differences among them.

- Long-range transported aerosols contributions overcame the $\mathrm{PM}_{10}$ local emission reductions benefits related to the lockdown.

\section{G R A P H I C A L A B S T R A C T}

Daily average concentrations of $\mathrm{SO}_{2}$ and $\mathrm{NO}_{2}$ from March 11 th to April 2nd in Salé city.
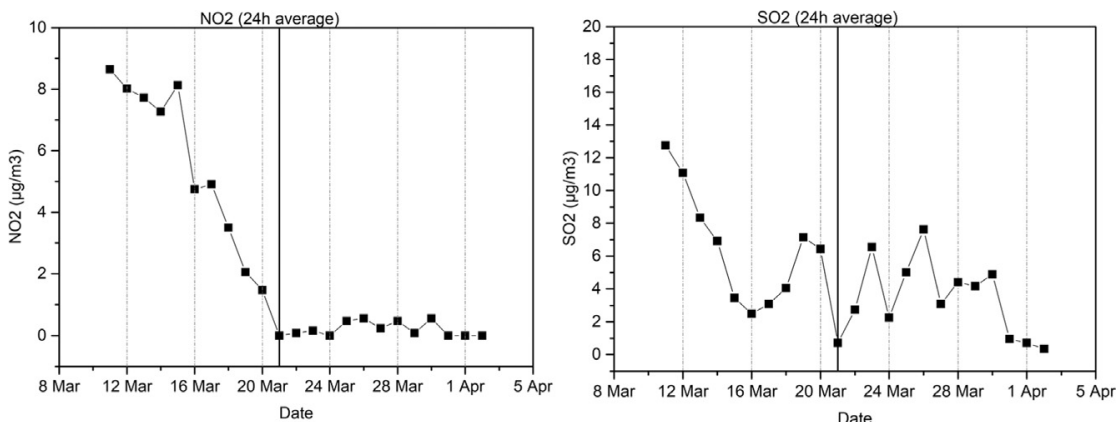

Date

\section{A R T I C L E I N F O}

\section{Article history:}

Received 10 May 2020

Received in revised form 15 May 2020

Accepted 17 May 2020

Available online 19 May 2020

\section{Keywords:}

Covid-19

$\mathrm{PM}_{10}$

$\mathrm{NO}_{2}$

$\mathrm{SO}_{2}$

Lockdown

Morocco

\begin{abstract}
A B S T R A C T
Covid-19 was first reported in Morocco on March 2, 2020. Since then, to prevent its propagation, the Moroccan government declared a state of health emergency. A set of rapid and strict countermeasures have taken, including locking down cities, limiting population's mobility and prohibiting almost all avoidable activities. In the present study, we attempted to evaluate the changes in levels of some air pollutants (mainly $\mathrm{PM}_{10}$, $\mathrm{NO}_{2}$ and $\mathrm{SO}_{2}$ ) in Salé city (North-Western Morocco) during the lockdown measures. In this context, a continuous measurement of $\mathrm{PM}_{10}, \mathrm{SO}_{2}$ and $\mathrm{NO}_{2}$ was carried before and during the Covid-19 lockdown period. As a consequence of the security measures and control actions undertaken, the emissions from vehicle exhaust and industrial production were significantly reduced, which contribute to the decrease in the concentrations of the studied pollutants. The obtained results showed that the difference between the concentrations recorded before and during the lockdown period were respectively $75 \%, 49 \%$ and $96 \%$ for $\mathrm{PM}_{10}, \mathrm{SO}_{2}$ and $\mathrm{NO}_{2}$. $\mathrm{PM}_{10}$ levels were much less reduced than $\mathrm{NO}_{2}$. The three-dimensional air mass backward trajectories, using the HYSPLIT model, demonstrated the benefits of $\mathrm{PM}_{10}$ local emission reductions related to the lockdown were overwhelmed by the contribution of long-range transported aerosols outside areas. In addition, noteworthy differences in the air mass back trajectories and the meteorology between these two periods were evidenced.

(c) 2020 Elsevier B.V. All rights reserved.
\end{abstract}

\footnotetext{
* Corresponding author at: National Centre for Nuclear Energy, Science and Technology (CNESTEN), BP 1382, 10001 Rabat, Morocco

E-mail address: benchrif@cnesten.org.ma (A. Benchrif).
} 


\section{Introduction}

Since the detection of realm's first case of the coronavirus (Covid19), on March 2, Moroccan authorities, for preventing the spread of the pandemic and preserving the health and safety of Moroccan citizens, have decided to declare a "state of health emergency" and taken a set of rapid and strict measures against Covid-19. All Moroccan cities were locked down, and the majority of industrial and commercial activities have been forced to stop their activities until further notice. For citizens, the authorities request them to stay at home and don't leave it except for very specific reasons (buy essential supplies, medical appointments...). In add to these safety actions, the authorities decide also to shut down transportation and travel in and out of the country, close down schools, universities, restaurants and mosques, and to ban the mass gatherings across Morocco (Maneesh and El Alaoui, 2020). However, some activities have been partially maintained as public service operation, pandemic prevention and control, and residential living needs. The Moroccan Government has decided to extend this sanitary state of emergency until 20 May 2020.

While the costs of these draconian countermeasures are undoubtedly enormous, several studies reported that reducing anthropogenic activities during Covid-19 outbreak plays a significant role in air pollution formation and could influence the total ambient air quality (He et al., 2020a; Isaifan, 2020). However, Wang et al. (2020) argued that the severe air pollution events would not be avoided by reducing anthropogenic activities (traffic and industrial activities) during Covid19 outbreak, particularly when meteorology is unfavourable. While the cities' lockdown could significantly improve the air quality, its effect may differ considerably across different types of cities. He et al. (2020a) find that more industrialized and colder cities experienced larger reductions in air pollution levels. Furthermore, Croitoru and Sarraf (2017) reported that the rigorous options to reduce the ambient air pollution in most Moroccan cities depending on the emission sources. For instance, air pollution from the transport sector can be decreased through the improvement of the transport system and/or promoting alternative modes of transport. Nevertheless, they highlighted that such options, among others, need to be carefully considered and adapted to the context of each city.

$\mathrm{PM}_{10}, \mathrm{NO}_{2}$ and $\mathrm{SO}_{2}$ are very common ambient air pollutants in urban environments and various studies carried out have demonstrated their severe health-related problems like respiratory and cardiovascular disorders, blood pressure, and lung cancer (Koken et al., 2003; Le Tertre et al., 2002). These regulated pollutants arise from anthropogenic sources, including road traffic (e.g., motor exhaust; brake, wear and road erosion; resuspension due to wheel-generated turbulence) and industrial activities (e.g., metal processing industry and waste management) (Thorpe and Harrison, 2008; He et al., 2020b). Besides the above emission sources, long-range pollution also plays an important role in certain worldwide countries. In Morocco, Benchrif et al. (2018) underlined the predominant influence of the trans-boundary pollution onto the northern cities air quality. In this context, the objective of the present paper is to assess the variations of $\mathrm{PM}_{10}, \mathrm{NO}_{2}$ and $\mathrm{SO}_{2}$ concentrations in the ambient air of Sale city before and during few days into the implementation of the lockdown measures against the propagation of Covid-19 pandemic.

\section{Materials and methods}

A continuous $\mathrm{PM}_{10}, \mathrm{SO}_{2}$ and $\mathrm{NO}_{2}$ measurements were carried out after and during the lockdown in Sale city, NW Morocco, located about $7 \mathrm{~km}$ northwest of the Kingdom's capital (Rabat), in an urbanresidential area. The measurements were carried out from 11 March to 02 April 2020 on Medersa des Merinides (Fig. 1), located about
$1.5 \mathrm{~km}$ west of the historical city centre (Médina). The instruments were set up on a terraced roof, approximately $10 \mathrm{~m}$ above ground level $\left(34.04^{\circ} \mathrm{N}, 6.83^{\circ} \mathrm{W}\right.$ ). Ambient air $\mathrm{PM}_{10}$ (aerosols $<10 \mu \mathrm{m}$ in diameter) were collected on pre-baked (at $500^{\circ} \mathrm{C}$ during $2 \mathrm{~h}$ ) $150 \mathrm{~mm}$ diameter QM-A Quartz fiber filters (Whatman ${ }^{\circledR}$ ). Daily samples were collected with high-volume (DA80, Digitel) sampler during $24 \mathrm{~h}$ with an operating flow rate of $30 \mathrm{~m}^{3} / \mathrm{h}$. To determine $\mathrm{PM}_{10}$ mass concentrations, filters were weighed before and after sampling using a Mettler Microbalance (Model MS304S) with $0.1 \mathrm{mg}$ precision. Filter weighing was achieved, in an acclimatized room for $24 \mathrm{~h}$ at an average temperature of $20 \pm 1{ }^{\circ} \mathrm{C}$ with atmospheric relative humidity maintained below $30 \%$. The uncertainty for each weighing was typically of the order of $20 \mu \mathrm{g}$, which represents an average uncertainty of $0.1 \%$ for $\mathrm{PM}_{10}$ measurements.

Low-cost electrochemical sensors, by ENVEA Cairpol, were used to collect high-resolution temporal data in real-time of $\mathrm{SO}_{2}$ and $\mathrm{NO}_{2}$. Moderate inter-comparison against reference measurements was performed. Before in-situ measurements, the sensors were colocated at a regulatory urban site in urban background conditions, where the performance of the calibration algorithms was explored. The uncertainty was typically of the order of $1 \mathrm{ppb}$ for each gas measurement.

Since the variability of pollutants is closely related to the immediate history of the air masses before arriving at the sampling site (Salvador et al., 2008), three-dimensional air mass backward trajectories were calculated using version 4.7 of the Air Resources Laboratory's Hybrid Single-Particle Lagrangian Integrated Trajectory (HYSPLIT ${ }^{\mathrm{TM}}$ ) model (Draxler and Rolph, 2003; Draxler et al., 2005). Three days backward trajectories arriving over sampling point were computed at 12:00 UTC at an elevation of $500 \mathrm{~m}$ above ground level. Then, cluster analysis technique was carried out to categorize the trajectories into distinct clusters (Benchrif et al., 2018). Furthermore, for investigating the role of the meteorology on the concentrations of studied urban air pollutants, meteorological data records were obtained from the weather station RabatSalé Airport $(34.05,-6.75)$, about $12 \mathrm{~km}$ from our sampling site (https://www.wunderground.com). The recorded metrological data were: wind speed $(\mathrm{m} / \mathrm{s})$, relative humidity $(\%)$, precipitation $(\mathrm{mm})$ and air temperature $\left({ }^{\circ} \mathrm{C}\right)$.

Finally, in an attempt to point out the main changes in $\mathrm{PM}_{10}, \mathrm{SO}_{2}$ and $\mathrm{NO}_{2}$ concentrations, their daily averages were calculated for the periods before (March 11th to 20th) and during the lockdown (March 21st to April 2nd). The objective was to evaluate the relative variation (in \%) and the difference in the mean concentration (in $\mu \mathrm{g} / \mathrm{m}^{3}$ ) between both periods of sampling.

\section{Results}

Comparisons between meteorological parameters prior to and during the lockdown period highlighted the existence of substantial differences between the two sampling periods (Table 1). Actually, the first period (before lockdown) was characterized by non-significant variations in temperature, relative humidity and low amount of rainy days ( $0.4 \mathrm{~mm}$ on average). However, the wind speed was steadily increased until the second period. For the second period (during the lock down), a high meteorology variation was observed: decrease in temperature (difference between averages: $-0.3{ }^{\circ} \mathrm{C}$ ), more humidity $(+1.9 \%$ ), windy $(+1.9 \mathrm{~m} / \mathrm{s})$, more amount of precipitation $(+0.1 \mathrm{~mm})$, and more rainfall days (percentage of the rainy days in the second period reached $69 \%$ ).

The inter-period variability of the final mean back trajectories resulting from the clustering process was examined for the periods prior to (March 11th to 20th) and following the lockdown (March 21st to April 2nd). For each period, the relative occurrence, direction 


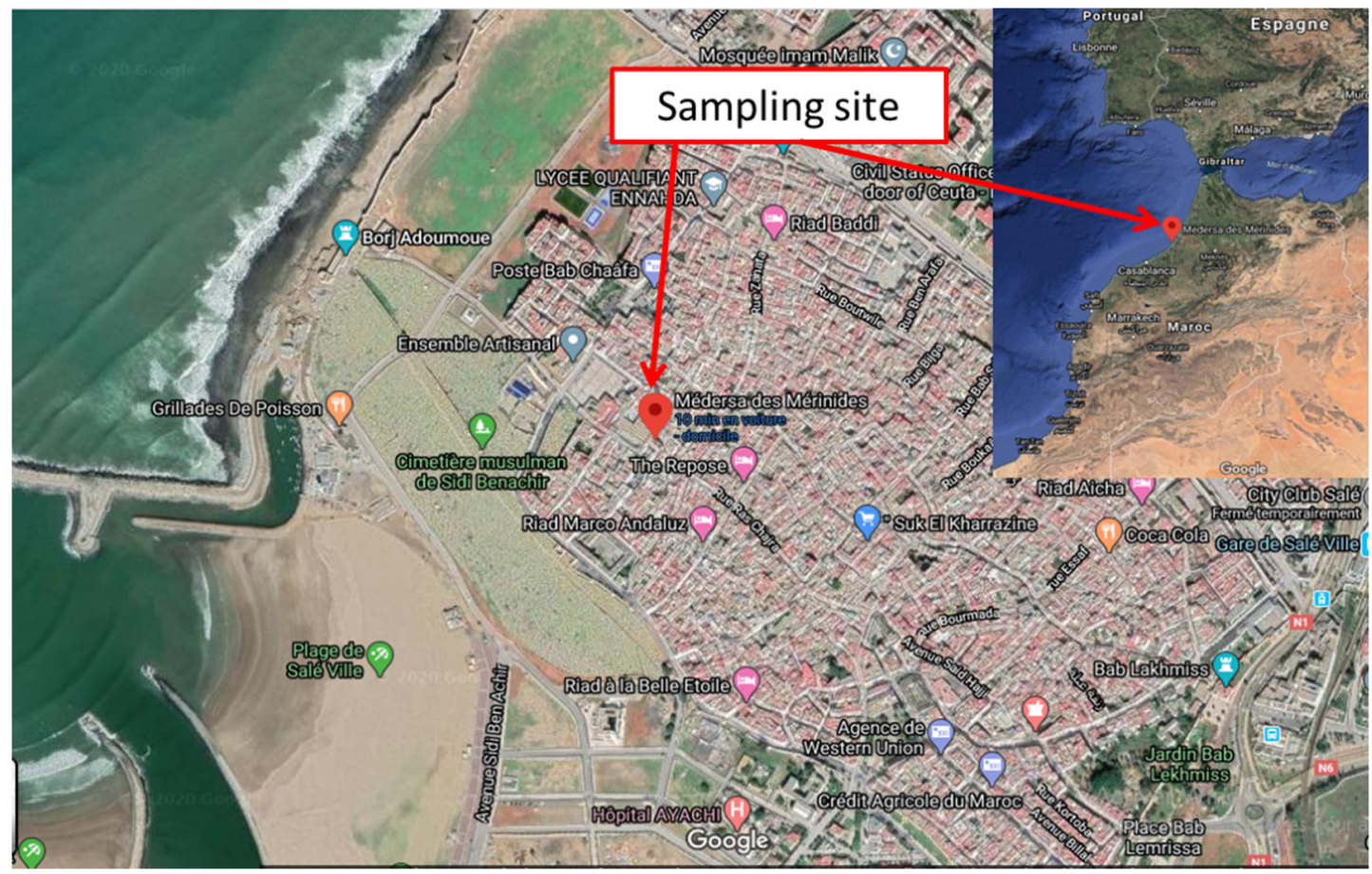

Fig. 1. Map showing the location of the sampling site $\left(34.04^{\circ} \mathrm{N}, 6.83^{\circ} \mathrm{W}\right)$.

and mean altitude of the five identified clusters are presented in Fig. 2. The period following the lockdown is dominated by air masses coming from the Northern and Western sectors generally accounted for $2 / 3$ of the period of concern, while the Eastern sector over the local continental and coastal environments for $1 / 3$. Particularities raised in the first period (before lockdown) accounting for strong winds from the North (across Portugal and Northern Morocco) then occurred over short periods of time. Overall, relevant cluster pattern differences were evidenced between both periods.

Fig. 3 provides daily variation of $\mathrm{PM}_{10}, \mathrm{SO}_{2}$ and $\mathrm{NO}_{2}$ concentrations before and after the lockdown. A dramatic decrease in the concentrations of $\mathrm{NO}_{2}$ (from 5.6 to $0.2 \mu \mathrm{g} / \mathrm{m}^{3}$ ) and $\mathrm{PM}_{10}$ (from 114.6 to $28.3 \mu \mathrm{g} / \mathrm{m}^{3}$ ) was recorded, which corresponds to a variation of $-96 \%$ and $-75 \%$, respectively. For $\mathrm{SO}_{2}$ concentrations, they dropped by $3.2 \mu \mathrm{g} / \mathrm{m}^{3}$ (from 6.6 to $3.3 \mu / \mathrm{m}^{3}$ ) accounted for $-49 \%$. The low $\mathrm{SO}_{2}$ concentrations recorded in the full study period $\left(4.75 \mu \mathrm{g} / \mathrm{m}^{3}\right.$ on average) do not allow evidencing a definite trend. Although all pollutant levels did not exceed the Moroccan air quality standard values (decree $n^{\circ} 2-09-286$ setting standards for air quality and the modalities for air monitoring, 2009) during the lockdown period, $\mathrm{PM}_{10}$ concentrations, in the first period, are higher than the daily reference value of $50 \mu \mathrm{g} / \mathrm{m}^{3}$.

Table 1

Mean concentrations of $\mathrm{PM}_{10}, \mathrm{SO}_{2}, \mathrm{NO}_{2}$ and averaged meteorological parameters observed in Sale city between March 11th to 20th (before the lockdown) and March 21st to April 2nd (during the lockdown).

\begin{tabular}{llcl}
\hline $\begin{array}{l}\text { Air pollutant/meteorological } \\
\text { parameter }\end{array}$ & $\begin{array}{l}\text { Before } \\
\text { lockdown }\end{array}$ & $\begin{array}{l}\text { During } \\
\text { lockdown }\end{array}$ & $\begin{array}{l}\text { Difference } \\
\text { [variation in \%] }\end{array}$ \\
\hline $\mathrm{PM}_{10}\left(\mu \mathrm{g} / \mathrm{m}^{3}\right)$ & 114.6 & 28.3 & $-86.3[-75]$ \\
$\mathrm{NO}_{2}\left(\mu \mathrm{g} / \mathrm{m}^{3}\right)$ & 5.6 & 0.2 & $-5.4[-96]$ \\
$\mathrm{SO}_{2}\left(\mu \mathrm{g} / \mathrm{m}^{3}\right)$ & 6.6 & 3.3 & $-3.2[-49]$ \\
Temperature $\left({ }^{\circ} \mathrm{C}\right)$ & 14.5 & 14.2 & $-0.3[-2]$ \\
Precipitation $(\mathrm{mm})$ & 0.0 & 0.1 & $0.1[+88]$ \\
Wind speed $(\mathrm{m} / \mathrm{s})$ & 6.0 & 7.9 & $1.9[+24]$ \\
Relative humidity $(\%)$ & 79.5 & 81.4 & $1.9[+2]$ \\
\hline
\end{tabular}

\section{Discussion}

From the obtained results, we could note that the government decisions in response to Covid-19 have impacted the air pollution in Salé city. So, the concentrations of $\mathrm{PM}_{10}, \mathrm{NO}_{2}$ and $\mathrm{SO}_{2}$, in the studied area, were decreased, respectively, by $75 \%, 96 \%$ and $49 \%$ within few days after implementation of Covid-19 countermeasures. Several studies (Ocak and Turalioglu, 2008; Dragomir et al., 2015) argued the effect of meteorology on the atmospheric concentrations of traffic-related pollutants. While the role of the meteorological parameters is quite evident in this study, they are not quantified.

The most significant variation was observed for $\mathrm{NO}_{2}$, a common tracer of urban air pollution/industrial activity. It is primarily resulted from high temperature combustion processes of fossil fuels, especially diesel, thermal power generation, industrial emissions, automobile exhaust and shipping (Burnett et al., 2004; Tobías et al., 2020). Biswas et al. (2019) reported that ambient $\mathrm{NO}_{2}$ is linked to many health hazards and its high concentrations can induce the formation of nitrate aerosols and acid rain. $\mathrm{NO}_{2}$ showed a significant decrease compared to the first period (before lockdown) when social and industrial activities were operating normally. Its rate reduction was much higher than those observed for $\mathrm{PM}_{10}$ and $\mathrm{SO}_{2}$. This could be explained by the fact that the emergency measures established by the Moroccan authorities, related to the cessation of industrial and transportation activities, had as a consequence a limitation in $\mathrm{NO}_{2}$ emission from both industrial production and vehicle exhaust, which has implicated a sharp decrease in $\mathrm{NO}_{2}$ concentrations during this period.

$\mathrm{SO}_{2}$ is one of the important indicators of air pollutants that are strongly related to the combustion of coal, petroleum, and chemical fuel emissions. It is the major precursor of nucleation formation of new particles in the atmosphere; and when these processes occur in populated regions, they could increase the human exposure to ultrafine particles (Kulmala et al., 2004). For the present study, the variations in $\mathrm{SO}_{2}$ concentrations were not higher compared to those of $\mathrm{PM}_{10}$ and $\mathrm{NO}_{2}$ because: $\mathrm{i}$ ) its levels appeared quite variable and significantly have decreased since the use, in 2009s, of fuel and lubricant oil with low sulphur contents; ii) commercial ships and incineration activities 

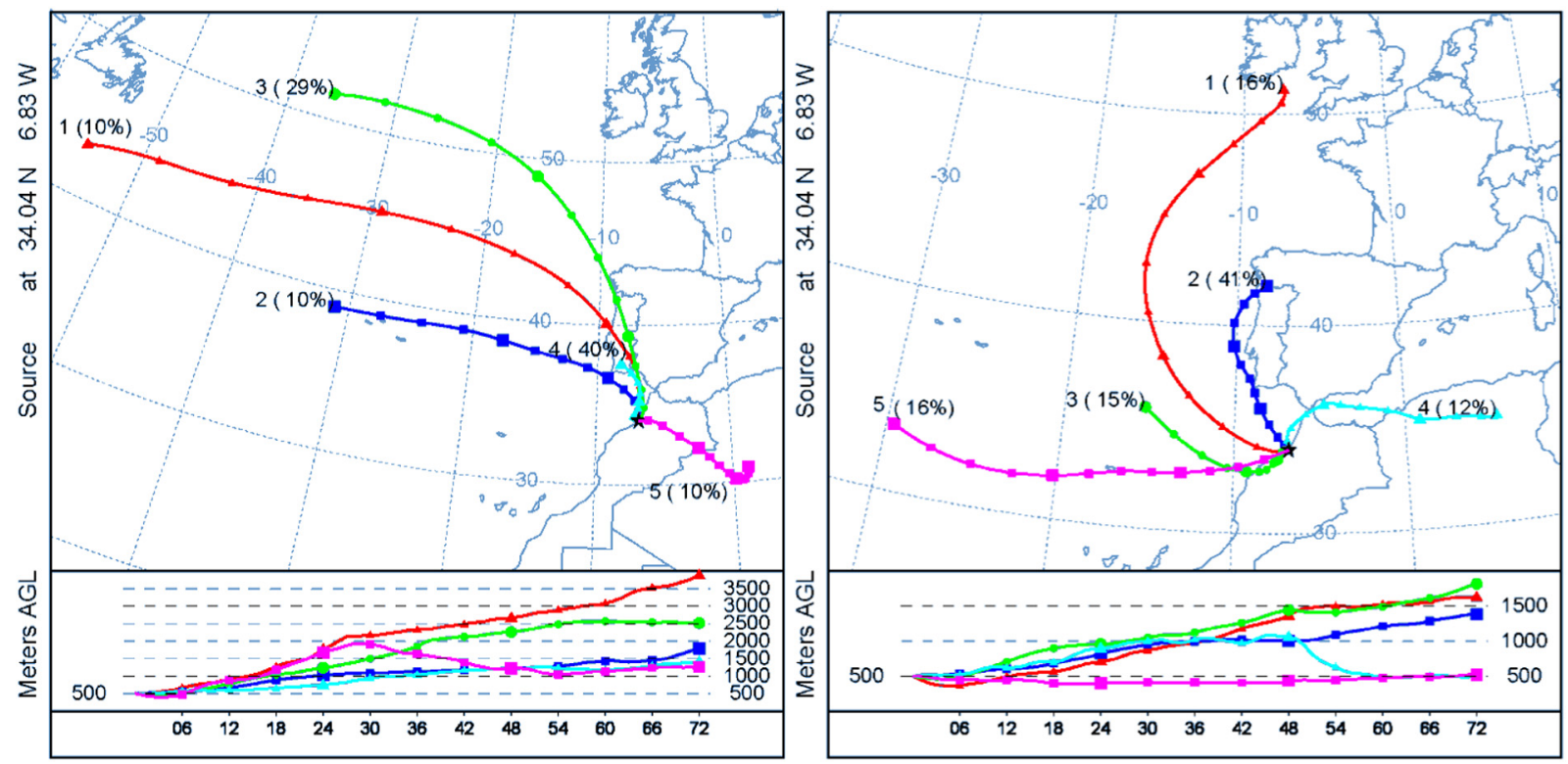

Fig. 2. Mean trajectories arriving at Salé from March 11th to 20th (left side) and from March 21st to April 2nd (right side) classified into 5 trajectory clusters.

(industrial zone and pottery complex around the sampling site) closures due to pandemic prevention and control actions contribute significantly in the reduction of $\mathrm{SO}_{2}$ emissions.

The pattern of $\mathrm{PM}_{10}$, derived principally from road traffic, industrial exhaust emissions, construction works and dust entrainment, can presumably reflect rapid decrease of traffic density and decline of the urban particulate emissions from a number of local sources. However, the back trajectory analysis portrayed that air quality in Salé urban area is mainly affected by PM originating from the Mediterranean Basin (characterized by marine vessel emissions out of Western Europe and Northern Africa), local continental and from the near Atlantic Ocean (affected by pollutants emitted from the Iberian coast).
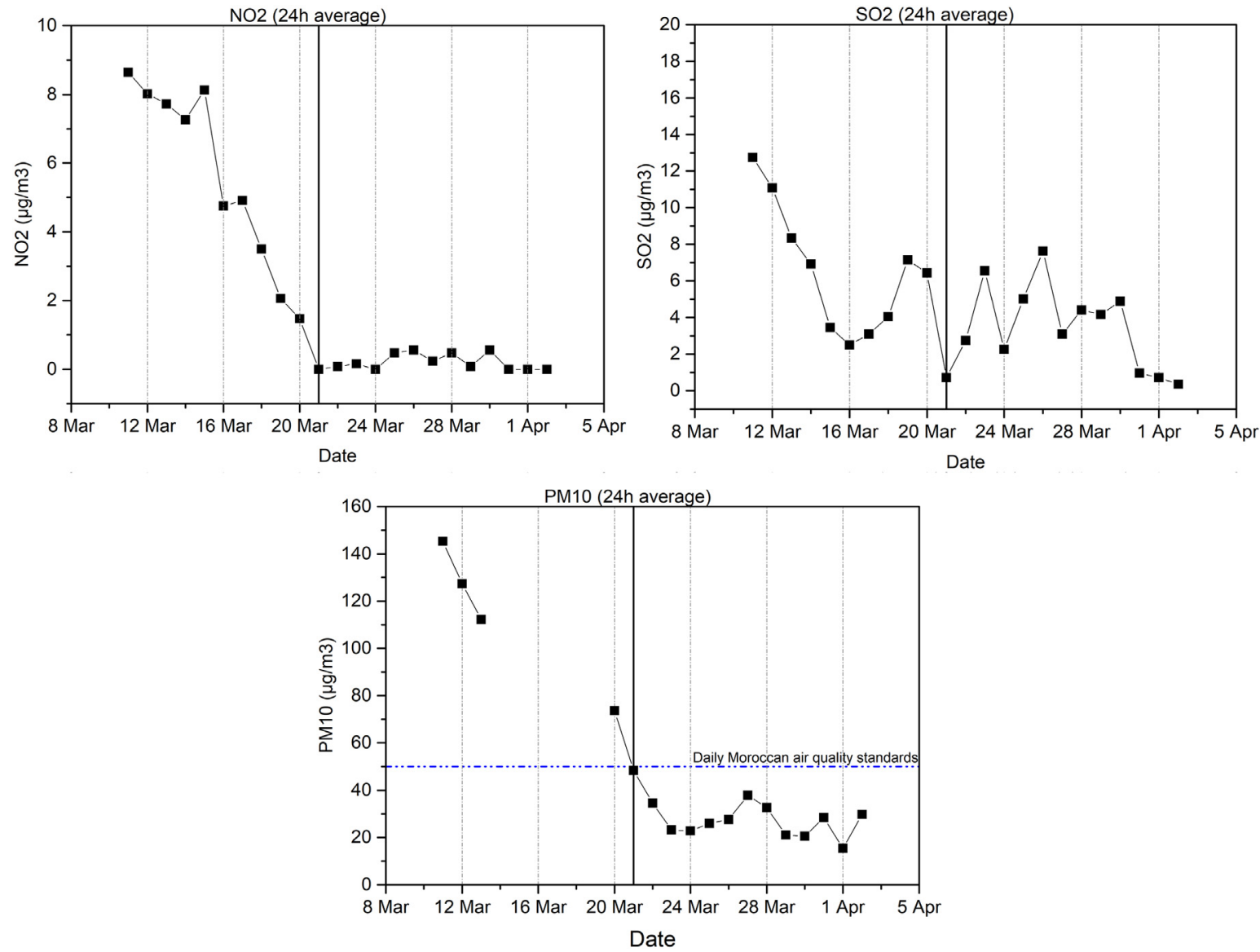

Fig. 3. Daily average concentrations of $\mathrm{PM}_{10}, \mathrm{SO}_{2}$ and $\mathrm{NO}_{2}$ from March 11th to April 2nd (with lockdown started on March 21st in Morocco) in Salé city. 
Indeed, the effects of reducing local air pollution on $\mathrm{PM}_{10}$ concentrations might still be limited due to the contribution of long-range transported particulate matter.

While $\mathrm{NO}_{2}$ and $\mathrm{PM}_{10}$ concentrations decreased since the strict implementation of pandemic prevention and control actions, their rate reduction and temporal gradients in the concentrations were significantly different. It would be hypothesized that the different amount of residence time of $\mathrm{PM}_{10}$ and $\mathrm{NO}_{2}$ in the atmosphere is another factor that might be implicated to understand their trends.

\section{Conclusion}

In conclusion, the reduction in $\mathrm{PM}_{10}, \mathrm{SO}_{2}$ and $\mathrm{NO}_{2}$ concentrations, in the studied area, can mainly be attributed to the drastic measures limiting human movement and industrial activities during the Covid-19 pandemic, which resulted in a significant reduction in emissions from vehicle exhaust and industrial production. The authors believe that the $\mathrm{PM}_{10}, \mathrm{NO}_{2}$ and $\mathrm{SO}_{2}$ concentrations will continue to decrease and keep down to minimal levels during the Covid-19 lockdown period.

\section{CRediT authorship contribution statement}

Anas Otmani: Conceptualization, Writing - original draft, Investigation. Abdelfettah Benchrif: Conceptualization, Writing - original draft, Supervision. Mounia Tahri: Writing - review \& editing, Supervision. Moussa Bounakhla: Supervision. El Mahjoub Chakir: Supervision. Mohammed El Bouch: Resources. M'hamed Krombi: Resources.

\section{Declaration of competing interest}

The authors declare that they have no known competing financial interests or personal relationships that could have appeared to influence the work reported in this paper.

\section{References}

Benchrif, A., Guinot, B., Bounakhla, M., Cachier, H., Damnati, B., Baghdad, B., 2018. Aerosols in northern Morocco: input pathways and their chemical fingerprint. Atmos. Environ. 174 (November 2017), 140-147. https://doi.org/10.1016/j.atmosenv.2017.11.047.

Biswas, M.S., Ghude, S.D., Gurnale, D., Prabhakaran, T., Mahajan, A.S., 2019. Simultaneous observations of nitrogen dioxide, formaldehyde and ozone in the Indo-Gangetic Plain. Aerosol Air Qual. Res. 19, 1749-1764.
Burnett, R.T., Stieb, D., Brook, J.R., Cakmak, S., Dales, R., Raizenne, M., Vincent, R., Dann, T., 2004. Associations between short-term changes in nitrogen dioxide and mortality in Canadian cities. Arch. Environ. Health 59, 228-236.

Croitoru, L., Sarraf, M., 2017. Estimating the health cost of air pollution: the case of Morocco. J. Environ. Prot. 8, 1087-1099. https://doi.org/10.4236/jep.2017.810069.

Dragomir, M.C., Voiculescu, M., Constantin, D.E., Georgescu, L., 2015. Prediction of the NO2 Concentration Data in an Urban Area Using Multiple Regression and Neuronal Networks. https://doi.org/10.1063/1.4937255 (December).

Draxler, Rolph, 2003. HYSPLIT (HYbrid Single-particle Lagrangian Integrated Trajectory) Model. NOAA Air Resources Laboratory, Silver Spring, MD access via NOAA ARL READY Website http://www.arl.noaa.gov/ready/hysplit4.html.

Draxler, Barbara, Glenn, Albion, 2005. HYSPLIT4 User's Guide. 4.7.

He, G., Pan, Y., Tanaka, T., 2020a. COVID-19, City Lockdown, and Air Pollution: Evidence From China. MedRxiv, 2020.03.29.20046649. https://doi.org/10.1101/ 2020.03.29.20046649.

He, L., Zhang, S., Hu, J., Li, Z., Zheng, X., Cao, Y., Xu, G., Yan, M., Wu, Y., 2020b. On-road emission measurements of reactive nitrogen compounds from heavy duty diesel trucks in China. Environ. Pollut. 262, 114280. https://doi.org/10.1016/j. envpol.2020.114280.

Isaifan, R.J., 2020. The dramatic impact of coronavirus outbreak on air quality: has it saved as much as it has killed so far? 6 (3), 275-288. https://doi.org/10.22034/ gjesm.2020.03.01.

Koken, P.J., Piver, W.T., Ye, F., Elixhauser, A., Olsen, L.M., Portier, C.J., 2003. Temperature, air pollution and hospitalization for cardiovascular diseases among elderly people in Denver. Environ. Health Perspect. 111 (10), 1312-1317.

Kulmala, M., Vehkamaki, H., Petaja, T., Dal Maso, M., Lauri, A., Kerminen, V.-M., Birmili, W. McMurry, P.H., 2004. Formation and growth rates of ultrafine atmospheric particles: a review of observations. J. Aerosol Sci. 35, 143-176.

Le Tertre, A., Medina, S., Samoli, E., Forsberg, B., Michelozzi, P., Boumghar, A., Vonk, J.M., Bellini, A., Atkinson, R., Ayres, J.G., Sunyer, J., Schwartz, J., Katsouyanni, K., 2002. Short-term effects of particulate air pollution on cardiovascular diseases in eight European cities. J. Epidemiol. Community Health 56, 773-779.

Maneesh, P., El Alaoui, Aicha, 2020. How Countries of South Mitigate COVID-19: Models of Morocco and Kerala, India. Available at SSRN:. https://ssrn.com/abstract=3567898 or. https://doi.org/10.2139/ssrn.3567898 (April 3).

Ocak, R.S., Turalioglu, F.S., 2008. Effect of meteorology on the atmospheric concentrations of traffic. 3 (5), 325-335.

Salvador, P., Artíñano, B., Querol, X., Alastuey, A., 2008. A combined analysis of backward trajectories and aerosol chemistry to characterise long-range transport episodes of particulate matter: the Madrid air basin, a case study. Sci. Total Environ. 390 (2-3), 495-506. https://doi.org/10.1016/j.scitotenv.2007.10.052.

Thorpe, A.J., Harrison, R.M., 2008. Sources and properties of non-exhaust particulate matter from road traffic: a review. Sci. Total Environ. 400, 270-282.

Tobías, A., Carnerero, C., Reche, C., Massagué, J., Via, M., Minguillón, M.C., Alastuey, A., Querol, X., 2020. Changes in air quality during the lockdown in Barcelona (Spain) one month into the SARS-CoV-2 epidemic. Sci. Total Environ. 726, 138540. https:// doi.org/10.1016/j.scitotenv.2020.138540.

Wang, P., Chen, K., Zhu, S., Wang, P., Zhang, H., 2020. Severe air pollution events not avoided by reduced anthropogenic activities during COVID-19 outbreak. Resour. Conserv. Recycl. 158 (March), $104814 . \quad$ https://doi.org/10.1016/j. resconrec.2020.104814 